\title{
Kulturøkonoma
}

\section{Og noget om kvinder og kultur}

\author{
Niels D. Lund
}

Kunne det tænkes der fandtes en figur man kunne kalde kulturøkonoma eller kulturhusholderske? Hvordan kunne den da beskrives og begrundes? Lad os gå via lidt begreb, lidt statistik, lidt biografi og en historisk parallel, for så at ende med et konkret forslag.

\section{Begreb}

Husholdning defineres i ordbøgerne som praktiske opgaver og deres udførelse inden for et afgrænset område, typisk hvor mennesker indgår i en helhed eller et (bolig)fællesskab og ofte med en arbejdsdeling. Det græske ord for husbestyrelse/husførelse er økonomi. Ordet statshusholdning kendes når der tales økonomi for staten som enhed, men det er næppe det der umiddelbart associeres til når budgetregnedrengene svinger de store tal. Moralske udmeldinger fra bekymrede ministre om ikke at have udgifter for mere end der er penge til, repræsenterer dog typisk en forenklet snusfornuft der kan minde om privathusholdningers.

Med ordet økonoma spores vi tættere ind på husholdningsbegrebet; det er femininum - ligesom husholderske er, og findes sjældent brugeligt som maskulinum økonomus - lige som heller ikke husholder gør det. Pr. lang tradition er vi med økonoma inde i

Niels D. Lund, lektor

Det Informationsvidenskabelige Akademi, Københavns Universitet,qtp573@hum.ku.dk et kvindeligt univers, som betegnelse for hende der i det nære regi og den knap så store skala har taget sig af husholdning, primært omkring køkken og fødevarer. Økonoma var igennem lang tid en respekteret uddannelse; hun havde væsentlige funktioner, dog også ledsaget af en række pejorative klicheer - stort stivet forklæde og kjole til under knæet, hårknold i nakken og fast, ugift blik. (I dag hedder økonomaernes forening lidt fladt Kost- og ernæringsforbundet).

En kulturhusholderske eller kulturøkonoma - kan betegnelsen overhovedet give mening? For én der tager vare på den kulturelle kost, den åndelige føde i stedet for køkkenets normale fødevarer. Kan man tale om en kulturel husholdning, både samfundsmæssigt og for den enkelte? Kan det eventuelt have noget specielt med kvinder at gøre - med en figur der holder sammen på noget vigtigt?

Vi skal ikke i retning af kulturøkonomi, endsige oplevelsesøkonomi; det er, ifølge Den Store Danske Encyklopaedi, den del af økonomividenskaben der beskæftiger sig med kulturlivets økonomiske forhold, og som med bl.a. statistiske modeller ser på om kultur samfundsmæssigt 'kan betale sig' og skaber vækst. Det er typisk en økonom der fagligt beflitter sig med det (- måske overvejende en mandlig sådan?) og som egentlig ikke behøver at have noget nært forhold til kultur. Modsat økonomaen der næppe udretter noget uden et nært forhold til hvad hun har mellem hænderne. 
At holde hus har et bredt betydningsfelt; ifølge Ordbog over det danske Sprog kan det være det samme som: at behandle noget på en sådan måde at det varer længe, og at anvende noget så man får fuld nytte af det - det er velkendt, og jo ikke så dårligt hvad angår kultur. Det kan også betyde: husere, tage på vej, skalte og valte med - hvilket jo er lidt drabeligt skræmmende, men helt fra Holbergs tids kan holde hus også angå: en støjende, vild lystighed, ligefrem en festen og sviren - og ad dén vej gælder det jo et tillokkende dionysisk forhold til kultur. Under mange omstændigheder synes der at være følelser med - og godt for det.

Kulturhusholdning kunne fremdeles pege på noget der gælder helheder og balancer: En kombination af indsigt i, forståelse af og dømmekraft omkring kulturytringer og deres betingelser, samtidig med opfyldning af behov og lystfyldt nærvær, og oplæg til æstetiske oplevelser og produktivt samvær; en afpasset respekt for at kultur koster, samtidig med at den opretholder liv; en balance mellem noget rationelt fagligt og noget følelsesbåret personligt og nært; den åndelige føde som både noget objektivt ernæringsrigtigt og samtidig en individuel sanselig nydelse. Kunne dét være pladsen for en moderne kulturøkonoma? Eller er det blot den plads en godt uddannet og personlig stærk kulturformidler allerede har? Kan husholdningsbegrebet og det kvindelige bidrage til at få øje på noget andet end det ellers i dag allestedsværende - kønsløse - formidlingsbegreb?

I det mangehovedede opslagsværk Kulturliv-en håndbog fra 1991 (Metz, 1991 - med en kvinde som den ene af tre redaktører), der beflittede sig med aktuel kulturpolitik, stigende arrangementskultur og meget andet, kunne man finde opslagsordet Kvindekultur - det eneste sted i bogen hvor køn var tænkt ind, og i øvrigt uden pendant i Mandekultur, den rigtige Kultur! Kvindekultur blev her beskrevet (af Hanne Møller) som et projekt der siden 1970erne fremstod som en art subkultur, og som skulle "... gøre kvinders skjulte verden synlig som reaktion på århundreders usynliggørelse af kvinders liv og kultur" (s. 176). Det anførtes videre at det efter et par årtier ikke gav mening at opretholde et enhedsbegreb som kvindekultur (- fx ville en kvindelig forfatter ikke mere kaldes en kvindeforfatter). Kvinderne havde i mellemtiden også støt bevæget sig ind i kulturinstitutionerne (i bibliotekerne havde de dog været længe) med prægning af både produktions- og formidlingsleddene samt medierne - og godt for det. Men omkring forbrugsleddet, receptionen, deltagelsen i kulturen, syntes der i imidlertid at være noget specielt, noget der kunne berettige til at tale om kvindelig kultur eller kvindekultur. Og stadig kan det.

\section{Statistik}

Som konsumenter og modtagere har kvinderne stået og står stadig stærkt i dansk kulturliv, de er de aktive og de dominerer felterne. Det dokumenteres af mange undersøgelser af kultur- og fritidsvaner, fx oversigten tilbage over årene 1975-98 (Fridberg, 2000), som viste at kvinder gik mere i teatret, på museer og til kunstudstilling, til klassiske koncerter og foredragsarrangementer, de kom mere på folkebibliotekerne, læste meget hyppigere end mænd - skønlitteratur dobbelt så meget som mændene, og de gik også mere til sang og kom i aftenskole og i kirke. Mht. biografibesøg og radiolytning stod kønnene omtrent lige, medens mændene var mere optaget af politiske møder, foreningsmøder (med mindre det var kulturelle foreninger) og især sportsarrangementer, fjernsyn og daglig avis, ligesom flere mænd spillede instrumenter.

Hvor kvinderne førte, var det ofte med $50 \%$ større aktivitet, og forskellen blev tilmed øget i de nævnte ca. 25 år. Den seneste kulturministerielle kulturvaneundersøgelse (Bak, 2012) befæster dette empiriske billede måske endnu tydeligere. Kvinder går stadig mest til opera, ballet, skuespil og klassisk koncert og på museumsudstilling (både kunst- og kulturhistorisk); nu går de også mere i biografen end mændene og er flittigere til at besøge kulturhistoriske bygninger og kulturmiljøer og deltage i byvandringer og kulturevents. De går fortsat mere til foredragsarrangementer og frekventerer læsekredse og aftenskole, og de ser støt mere tv. Kvinders folkebiblioteksbesøg er flere og hyppigere, de låner mere end mændene og deltager mere i biblioteksarrangementer, og de læser både til daglig og i ferier meget mere skønlitteratur, og nu også mere faglitteratur end mænd. Kun omkring musikfestivaler, entrébelagte sportsarrangementer, computerspil og avislæsning fører mændene. Helt tydeligt er kvinderne bedre til at komme ud til kulturen uden for hjemmet, især dem mellem $30 \mathrm{og}$ 60 år.

Kultur kan være andet end hvad der opfanges i disse undersøgelser, men forskellene er markante. At det 
især er kvinder over 50 år som er aktive og storforbrugere, kan forklares med et støt stigende uddannelsesniveau, med at børn er fløjet af reden og har tilført tid, og måske også med kvinders initiativ- og samværsformer. Disse gennem årtier kendte forskelle og dette skæve billede - denne kvindekultur, denne husholdning - har imidlertid egentlig aldrig været udforsket dybtgående i Danmark.

Den 8. marts 2016 - kvindernes internationale kampdag - bragte dagbladet Politiken en artikel om at det er kvinderne der bærer kulturlivet. Ud fra undersøgelser som de ovennævnte fremstår hende der bærer som en 55-årig velklædt kvinde fra hovedstadsområdet med en videregående uddannelse. $\mathrm{Og}$ hun $\mathrm{og}$ hendes lige betegnes i udtalelser til artiklen af rigtig mange kulturinstitutionsledere som dem der holder det danske kulturliv i gang; ja hun hyldes - som trofast og opsøgende med nærvær og sikker fornemmelse. Hendes engagement har tilmed været med til at omdefinere og flytte kulturinstitutionerne - bl.a. gøre dem til mere socialt aktive møderum, og til at forvandle kunst og kultur til en social begivenhed og samtale. "Man kan anskue hende som et åbent system af relationer, hvor alle omkring hende inviteres med eller påvirkes af hendes engagement i kulturlivet", siger en (kvindelig) kunstmuseumsdirektør om kulturbæreren.

Institutionslederne anfører at det moderne (trods alt) støt mere dialogisk orienterede kulturliv i stigende grad indretter sig efter denne attraktive gruppe. Den er for markant til at ignoreres. De nævnte empiriske undersøgelse og institutionsledernes taknemmelige glæde bør og må kalde på nøjere interesse: hvis ikke det er en art kvindekultur på kulturens område (og slet ikke i 1970ernes forstand), kunne det så være en art kulturhusholdning? Artiklen kaldte dem kulturkvinder, hvad er det de holder hus med, hvad dækker deres sviren?

\section{Biografi}

Hvordan kan man være i kulturlivet? Det kan man bl.a. som lønarbejder på forskellig vis, herunder som iagttager og analytiker, som forsker med videnskabens nøgterne, uhildede distance, som kulturforsker. Dorte Skot-Hansen er som kultursociolog kulturforsker, med en mere end 40 år lang akademisk karriere bag sig, på Danmarks Biblioteksskole, nu Det Informationsvidenskabelige Akademi, Københavns
Universitet. Mangfoldige sider af kulturlivet - folkekultur, museer, biblioteksteori, kulturforsøg, oplevelsessamfund etc. er blevet gransket og evalueret, og i utallige sammenhænge har hun styret, rådgivet og foredraget, nationalt og internationalt. Der har dog aldrig været lagt nogen specielt kønsorienteret synvinkel (endsige egentlig feministisk forskning) fra Dorte Skot-Hansens side. Det har været kulturlivet i mangfoldige aspekter, helt uanset køn. Heller ikke ovennævnte markante forskel i kulturforbrug/-deltagelse har været berørt. Det havde ellers været stærkt forventeligt af en akademiker i den generation, og ud fra køn, miljø og observans - og lidt af en gåde? Snarest ligner det en strategi: blandt de førende forskere på sit felt skal man som kvinde ikke skille sig ud og gå specielt efter kønsrelaterede problemstillinger. Det sku' nødig hedde sig ..., der holdes hus med det! Heller ikke de mange årtier midt i folkebiblioteksfaget og -uddannelsen, der har været et udpræget kvindemiljø, har afficeret Dorte Skot-Hansens sociologifaglige tilgang eller ståsted.

Det ret nye fag kultursociologi, halvt samfunds- halvt humanvidenskabeligt, fra midten af 1960erne blev karrieregivende for Dorte Skot-Hansen. Men var og er der andre indfaldsveje, omveje eller genveje - måske endog personlige eller private? Med en opvækst i faderens danske og internationale filmmiljø, og nogle år af barndommen boende i Hollywood, med en mormor med en violinistkarriere in spe, en ægtemand der var kunstmaler, en anden ægtemand der har arbejdet med teaterverdenen, med en søn der er dramatikeruddannet og lever som forfatter har det ikke skortet på omgang med kunst og kultur, miljøpåvirkning og inspiration, foruden alle de tilsvarende interesserer $\mathrm{i}$ store dele af omgangskredsen. Film, billedkunst, dramatik og litteratur har så ikke været de felter der har fyldt mest i Dorte Skot-Hansens rent faglige spænd - det sku' nødig hedde sig... Et fint lille skrift om mormoren og hendes højborgerlige miljø: Sommerliv med mormor - Elly Henriques (Skot-Hansen, 1994) vidner dog om at blikket for kvindeliv har været der, men så (netop) holdt på det privatbiografiske plan. Der holdes hus med tingene.

Kontakt med kulturlivet på anden måde end rent teoretisk og dokumenterende? Ja, via mange råd, udvalg og bestyrelser har Dorte Skot-Hansen haft stor involvering og social kontakt i kulturkredse, mængder af arrangementer, events og besøg. (Der ligger en anseelig forskningsopgave $i$ at udrede sammenhænge 
mellem bestyrelsespladser og fribilletter!). Store dele af hendes aktiviteter og rejseri har antagelig været en uigennemskuelig sammenblanding af faglige og personlige interesser, hvor der dog også typisk (eller for det meste) er holdt hus med grænserne og balancen mellem arbejde og fritid.

Når nu veluddannede (og velklædte) kvinder med børnene af reden og forbi de 50 år er de aktive og bærerne af dansk kulturliv, burde Dorte Skot-Hansen så ikke netop indgå i den gruppe? Det gør hun om nogen - med besøg i biograf og teater, på udstillinger og til festivaler, bogmesser og allehånde events (obs. fribilletterne!) samt med skønlitterær læsning og medlemskab af læsekreds (- disciplinen i læsekredsen, bestående af kvinder med fuld statistisk demografi, tilsiger at der pr. mødegang og pr. deltager kun må omtales én fysisk gebrækkelighed og ét barnebarn). En uge er ofte tæt kulturpakket (- inklusive lidt kropskultur ind imellem). Dorte Skot-Hansen opfylder alle kriterier for at være den kvindelige kulturforbruger og -bærer, ofte mingeleret via venindeaftaler. Hun inkarnerer i sin fritid det kulturliv hun er så fagligt fortrolig med. Hun ved det godt (- og koketterer af og til med det), billedet hænger sammen. Men det skilles også ofte ad; der skal holdes hus med at være både iagttager som fagkvinde og deltager som privatperson, også derved at feminismen stikker mere frem personligt end den gør fagligt.

Evne og vilje til traditionel hjemmehusholdning udgør næppe Dorte Skot-Hansens primære ambition eller identitet (selv om hun godt kan noget på feltet, især når der er fest). Det angiveligt varige indtryk af den - musikbegavede - højborgerlige mormors generøse samlerskikkelse med fuldt styr på - netop et stort hushold synes Skot-Hansen at have overført til sin egen husholdning med kulturen; den er derfor eller til gengæld omfattende og storsindet, dreven og privilegeret.

\section{Historieparallel}

Suhrs Husholdningsskole blev etableret af frk. Ingeborg Rasmine Dorthea Suhr i København i 1901. Hun fik på baggrund af aner i det københavnske borgerskab, egen bred uddannelse og en imposant foretagsomhed etableret en privat, eksamensbåret husholdningsskole, senere -seminarium. Helt fra begyndelsen var der "fokus på madkvalitet, æstetik og omtanke for omverdenen og miljøet", som institu- tionens hjemmeside i dag fortæller historien. Hvem som helst var frk. Suhr naturligvis ikke - ifølge Dansk Kvindebiografisk Leksikon: "Hendes mod, handlekraft, begavelse og stræben blev igangsættende for udviklingen inden for et af samfundets mest traditionsbundne områder". Og karakteristikken af hende fortsætter ind i en kontekst for åndelig føde: "I fritiden dyrkede hun sine kulturelle interesser, fulgte forelæsninger, deltog i politiske møder, lærte sprog m.v. Hun deltog også i litterære aftener hos digteren Viggo Stuckenberg, hvilket bragte hende i forbindelse med datidens intellektuelle miljø".

Succesrigt har hendes skoler været førende langt frem i tiden. Nylig er en del af dem gået ind i professionsbachelor-uddannelse på Metropol; en anden del af dem er endt som Danmarks eneste folkehøjskole for mad - og tilmed med Madakademiet som ekstranavn; ifølge hjemmesiden gælder det:"... ikke bare hverdagsmadlavning, men også smagssammensætninger, sundhed, kommunikation, eventopbygning, æstetik og råvarer". Hvad der begyndte i et miljø for borgerskabets kvinder, står nu bredere folkeligt på højskoletraditionens grund. Mad som oplivelse, dvs. at indgyde livsmod og gøre glad, føle sig værdsat og dermed se en mening med hvad man er i gang med for at tale grundtvigsk-koldsk. Dér må det være godt at være med - medværd. En kvindekultur der blev til folkekultur - og som mændene antagelig også har fået mere del i. Husholdning og kost indgår i helheder, køkkenet som selvfølgelig kulturbærer.

\section{Forslag}

Således inspireret kunne det vel også være muligt at tænke en kulturhusholdnings-højskole? Åndelig føde på højskolerne (hvor man i øvrigt netop spiser sammen) er jo langt fra heller noget nyt, tværtimod.

En højskole har det prærogativ ikke at give nogen formel uddannelse; så vist som der næppe heller er brug for nye kulturformidleruddannelser og eksamener. En højskole henter status og niveau fra viden, men nok så meget fra erfaring, dannelse, nysgerrighed, dømmekraft og nærvær. Det er måske præcis hvad kultur er - frem for noget akademisk? Man skal lære at have noget i sig - det kunne hushold være en god metafor for. En forædling inden for kulturel husholdning, frembragt måske af gode husholdersker. Få indgydt vaner og grundholdninger omkring kultur i livet, få balanceret vilje til at opleve, anstrenge sig på 
en behagelig måde, være opmærksomt med, sortere og huske, blive generøs. Har man ikke generøsiteten med sig, får man den - af afpasset kulturhusholdning. Overskud hentes når åndelige og æstetiske udtryk forbindes med opmærksomme samværsformer kulturens sociale aspekt, medregnet forhåbentlig de mandlige højskoleelever i fælleskøkkenet. En folkehøjskole eller et akademi med fokus på åndelig føde - den kunne hedde Skots Kulturhusholdningsskole. Fra Suhrs til Skots!

Ingeborg Suhr var godt 30 da hun brød igennem med sit; navnefællen Dorte Skot-Hansen ca. det samme da hendes forskning i kultur tog retning - bl.a. omkring folkekultur. Nu er hun lidt ældre (- der er dog langt til de næsten 100 år som Ingeborg fik). Men skulle hun finde på at oprette denne skole for kulturens husholdning, evt. for en slags kulturelle økonomaer, på folkeligt grundlag, ville hun have et afsæt for det. Ikke kun faglige kompetencer og kvalifikationer, men også sind og stil; og netop nu med helt fri holdning til traditionel videnskabelighed og offentlige institutioner. At blive grundlæggerske skulle være nemt nok (- med lidt overtalelse); er der ikke ork til at være daglig rorgængerinde på sådan et sted, ville Dorte Skot-Hansen klart kunne få tilknytning og titel som seniorkulturøkonoma. At være i hus med og holde hus med kulturen - oplevelse og erfaring fundet og forbundet med viden, lyst og sviren - er aldrig for sent.

\section{Referencer}

Bak, L et al. (2012). Danskernes Kulturvaner 2012. København: Epinion og Pluss Leadership.

Fridberg, T (2000). Kultur- og fritidsaktiviteter 1975 -1998. København: Socialforskningsinstituttet.

Metz, G, Skot-Hansen, D \& Skyum-Nielsen E (1991). Kulturliv - en håndbog. København: Munksgaard.

Skot-Hansen, D (1994). Sommer med mormor-Elly Henriques. Frederiksbeg: Eget forlag.

Sørensen, S (2016). Kvinder bcerer kulturlivet. Politiken 8.3.2016, sektion 2. 